\title{
$\mathrm{Al}-\mathrm{Mg}-\mathrm{Si}$ 合金のベークハード性に及ぼす高温予備時効と その前後の自然時効の影響 *
}

\author{
八太 秀周 $* *$ ・松田 眞一 $* *$ *田中 宏樹 $* *$ 吉田 英雄 $* *$
}

Journal of Japan Institute of Light Metals, Vol. 59, No. 5 (2009), pp. 248-253

\section{Effects of pre-aging at elevated temperature and natural aging on the bake hardenability of $\mathrm{Al}-\mathrm{Mg}-\mathrm{Si}$ alloy*}

\author{
Hidenori HATTA**, Shinichi MATSUDA $^{* *}$, Hiroki TANAKA** and Hideo YOSHIDA**
}

\begin{abstract}
Effects of natural aging before pre-aging, pre-aging and natural aging after pre-aging on the bake hardenability of the $\mathrm{Al}-0.62 \mathrm{mass} \% \mathrm{Mg}-0.96 \mathrm{mass} \% \mathrm{Si}$ alloy have been studied by tension test, hardness measurement, electrical resistance measurement and differential scanning calorimetric analysis (DSC). The bake hardenability after natural aging at $20^{\circ} \mathrm{C}$ for $86.4 \mathrm{ks}$ was improved by pre-aging between $100^{\circ} \mathrm{C}$ and $170^{\circ} \mathrm{C}$. In the case of short pre-aging at $100^{\circ} \mathrm{C}$, the bake hardenability started to decrease after natural aging for more than $86.4 \mathrm{ks}$, because the amount of clusters of solute atoms increased. Natural aging before pre-aging causes decreasing the bake hardenability because the clusters formed during natural aging before pre-aging.
\end{abstract}

(Received October 24, 2008 Accepted December 26, 2009)

Keywords: $A l-M g-S i$ alloy, bake hardening, natural aging, DSC analysis

\section{1. 緒言}

自動車の燃費向上を目的として車両の軽量化が進められて おり，アルミニウム合金板の自動車ボディへの適用が増加し つつある ${ }^{1)}$ 。6 000 系アルミニウム合金の自動車ボディ材には, プレス成形時には耐力が低く成形性が良好なこと，塗装焼付 け工程の加熱を利用して硬化し（Bake hardening, 以下 BH 処 理と称す), 最終製品では高い耐力であることが求められて いる。しかし 6000 系アルミニウム合金では溶体化処理後か ら BH 処理されるまでの自然時効により，ベークハード性が 低下することが知られていること 2) 5) から，その対策として 高温予備時効処理 6) 9） と復元処理 10）を行う方法が開発され た。特に高温予備時効処理に関しては研究が盛んであり, 溶 体化処理後に直接高温予備時効処理温度に焼入れしその温度

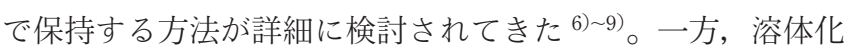
処理後にいったん室温付近に焼入れし，その後再加熱して高 温予備時効処理する方法 ${ }^{7)}$ ああるが，溶体化処理後に室温付 近の温度へ焼入れするため, 焼入れ直後から高温予備時効の 開始までが自然時効となる。さらに 6000 系自動車ボディパ ネル材では，アルミニウムメーカより $\mathrm{T} 4$ 調質で出荷され， その後 BH 処理されるまでに，運搬やプレス工程などがある ことから，溶体化処理後塗装焼付けを開始するまでが自然時 効状態となる。すなわち熱履歴としては，焼入れ直後から高 温予備時効を開始するまでの自然時効, 高温予備時効, その 後 BH 処理を開始するまでの保管による自然時効，最後に BH 処理の合計四段階の時効処理になる。そのため時効挙動の制
御が一層複雑になると思われる。それらの時効の相互関係を 明確にすることはべークハードを利用する上で不可欠である。

そこで本研究ではベークハード性に及ぼす高温予備時効前 の自然時効, 高温予備時効, その後の自然時効の影響につい て，三段および四段時効での挙動を調査した。

\section{2. 実 験方法}

半連続鋳造により Table 1 に示す化学組成の鋳塊を作製 し, $560^{\circ} \mathrm{C}$ で $36 \mathrm{ks}$ の均質化処理をした後, $500^{\circ} \mathrm{C}$ の温度にて 厚さ $30 \mathrm{~mm}$ から $4 \mathrm{~mm}$ まで熱間圧延した。その後, 厚さ $4 \mathrm{~mm}$ から $1 \mathrm{~mm}$ まで冷間圧延を行い供試材とした。Fig. 1 に熱処

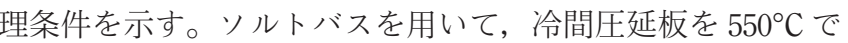
$0.06 \mathrm{ks}$ 保持の条件で溶体化処理を行った後, 水水中に焼入れ した。本系合金は焼入れ後のわずかな室温保持でもべーク 八ード性の低下が報告 ${ }^{4)}$ されているため，焼入れた水水中で の保持を $0.01 \mathrm{ks}$ とした。続けて自然時効なしにオイルバスを 用いて $80^{\circ} \mathrm{C}$ から $170^{\circ} \mathrm{C}$ の温度で $0.24 \mathrm{ks}$ から $7.2 \mathrm{ks}$ 保持の高温 予備時効処理を行った。比較として高温予備時効処理なし材 も作製した。その後, 直ちに $20^{\circ} \mathrm{C}$ の恒温槽（大気）で自然 時効を最大 $604.8 \mathrm{ks}$ まで行い，最後にオイルバスを用いて

Table 1 Chemical composition of the alloy (mass \%)

\begin{tabular}{c|c|c|c}
\hline \hline $\mathrm{Mg}$ & $\mathrm{Si}$ & $\mathrm{Fe}$ & $\mathrm{Al}$ \\
\hline 0.62 & 0.96 & 0.03 & $\mathrm{Bal}$. \\
\hline
\end{tabular}

*第 106 回春期大会（平成 16 年 5 月）で一部発表。

**住友軽金属工業(株研究開発センター（～455-8670 愛知県名古屋市港区千年 3-1-12)。 Research and Development Center, Sumitomo Light Metal Industries, LTD. (3-1-12 Chitose, Minato-ku, Nagoya, Aichi 455-8670).E-mail: hidenori_hatta@mail.sumitomo-LM.co.jp 


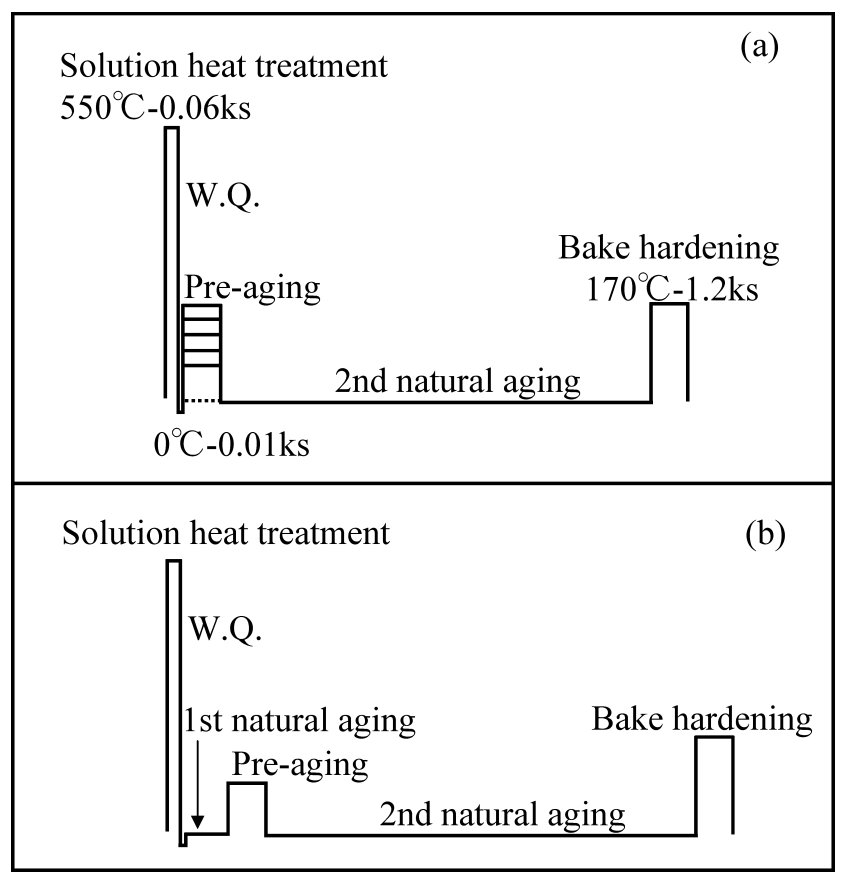

Fig. 1 Schematic diagram of heat treatment, (a) three step aging, (b) four step aging.

$170^{\circ} \mathrm{C}$ で $1.2 \mathrm{ks}$ の $\mathrm{BH}$ 処理の合計三段の時効処理を行った。さ らに焼入れ後から高温予備時効を開始するまでの自然時効を 想定し, 恒温水槽を用いて $20^{\circ} \mathrm{C}$ で最大 $3.6 \mathrm{ks}$ の自然時効を高 温予備時効前に追加して合計四段の時効処理を行った試料む 作製した。

引張性質の調査は, 圧延方向に対して平行方向に採取した JIS 5 号引張試験片を用いて $\mathrm{BH}$ 処理前 $\left(20^{\circ} \mathrm{C}\right.$ 自然時効後）お よび BH 処理後に実施した。ビッカース硬さ測定は負荷荷重 $49 \mathrm{~N}$ の条件で, BH 処理前㧍よび BH 処理後に測定した。時 効挙動の解析には電気抵抗測定之熱分析を用いた。電気抵抗 測定では $1 \times 2 \times 200 \mathrm{~mm}$ の試験片を用いて, 恒温水槽中で $20^{\circ} \mathrm{C}$ の自然時効を行っている際の電気抵抗変化を四端子法に よりその場測定した。熱分析は入力補償型 DSC を用いて, $\mathrm{BH}$ 処理前の試料について測定した。従来, 昇温速度は $5 \sim 20^{\circ} \mathrm{C} / \mathrm{min}$ にて測定した報告 ${ }^{9), 12)}$ が多いが, 室温付近での 測定中の時間経過に伴う自然時効の影響をさけるために, 昇 温速度の大きい $40^{\circ} \mathrm{C} / \mathrm{min} に て$ 測定した。

\section{3. 結果および考察}

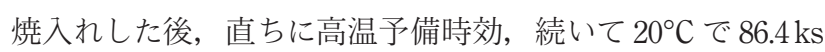

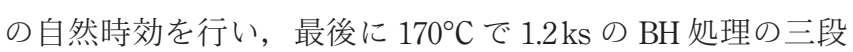
時効を行った。その $\mathrm{BH}$ 処理前後の耐力に及ぼす高温予備時 効の影響を Fig. 2 に示す。BH 処理前の耐力は高温予備時効 温度が高いほど，保持時間の増加に伴い急激に上昇した。高 温予備時効の温度が $80^{\circ} \mathrm{C}$ の場合には高温予備時効時間を増 加しても BH 処理後の耐力に大きな変化がみられなかったの に対し， $100^{\circ} \mathrm{C}$ 以上の温度で高温予備時効を行った場合には, 高温予備時効時間の増加に伴い, 緩やかに $\mathrm{BH}$ 後の耐力が上 昇した。これらのことから, BH 処理前後の耐力ともに高温 予備時効の温度と保持時間に大きく影響されることが確認で きた。

$\mathrm{BH}$ 処理前の耐力と $\mathrm{BH}$ 処理後の耐力の差で表されるべー

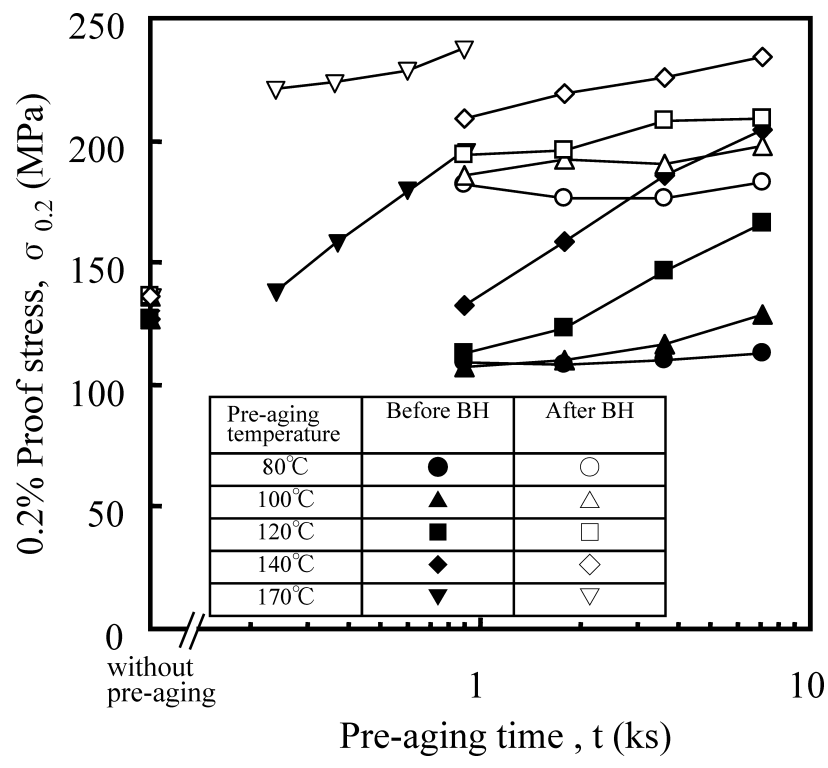

Fig. 2 Effect of pre-aging condition on the $0.2 \%$ proof stress of the alloy before $\mathrm{BH}$ treatment and after $\mathrm{BH}$ treatment. The samples were pre-aged after water quenching followed by $2 \mathrm{nd}$ natural aging at $20^{\circ} \mathrm{C}$ for $86.4 \mathrm{ks}$, then baked at $170^{\circ} \mathrm{C}$ for $1.2 \mathrm{ks}$.

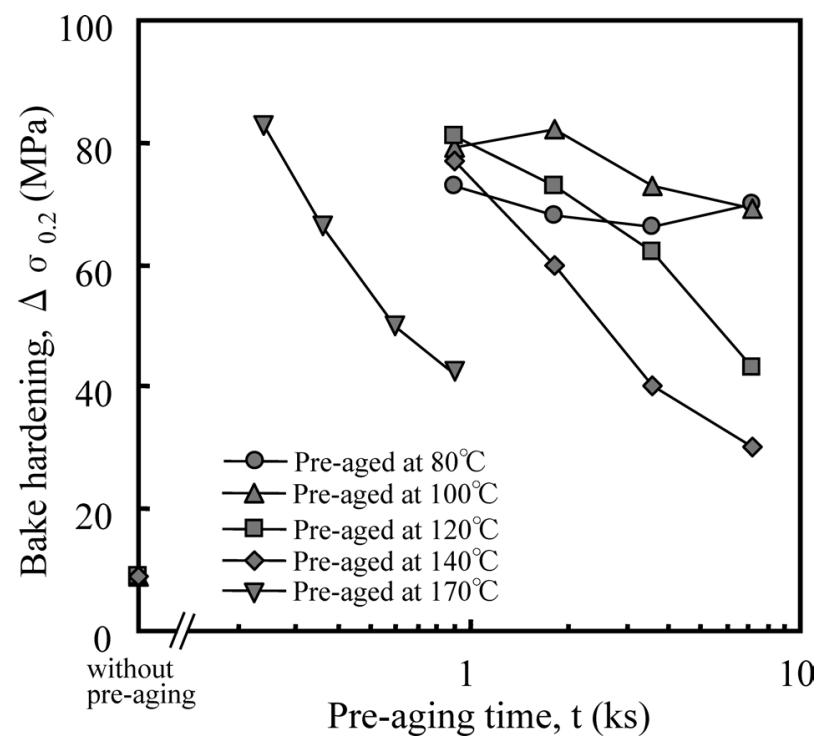

Fig. 3 Effect of pre-aging condition on the bake hardenability for $0.2 \%$ proof stress. The samples were pre-aged after water quenching followed by 2 nd natural aging at $20^{\circ} \mathrm{C}$ for $86.4 \mathrm{ks}$, then baked at $170^{\circ} \mathrm{C}$ for $1.2 \mathrm{ks}$.

クハード量と高温予備時効の関係を Fig. 3 に示す。高温予備 時効の温度が高いほど短時間で大きなベークハード量に達し た。しかし $170^{\circ} \mathrm{C}$ のような高温での予備時効は, 保持時間の 増加に伴うべークハード量の低下は顕著であった。今回の試 験条件の範囲において, 各高温予備時効温度の最屯大きい ベークハード量を比較すると, $80^{\circ} \mathrm{C}$ より $100^{\circ} \mathrm{C}$ 以上の高温予 備時効の方が, 大きいベークハード量に達していた。高温予 備時効温度 $100^{\circ} \mathrm{C}, 120^{\circ} \mathrm{C}, 140^{\circ} \mathrm{C}, 170^{\circ} \mathrm{C}$ の比較では大きな差 はみられなかった。以上の結果より $100^{\circ} \mathrm{C}$ から $170^{\circ} \mathrm{C}$ のい゙ れの高温予備時効処理温度でも高いベークハード性が得られ るものの, 温度が高い場合には高温予備時効中の保持時間が 


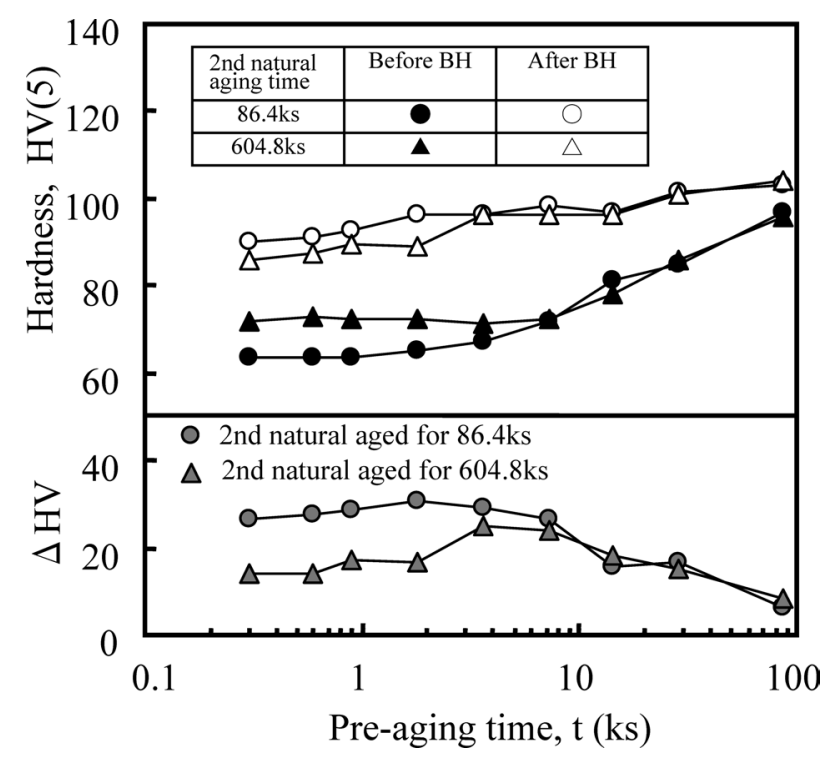

Fig. 4 Changes in hardness with pre-aging time at $100^{\circ} \mathrm{C}$ before $\mathrm{BH}$ treatment and after $\mathrm{BH}$ treatment at $170^{\circ} \mathrm{C}$ for $1.2 \mathrm{ks}$. The samples were pre-aged at $100^{\circ} \mathrm{C}$ for various times after water quenching followed by 2 nd natural aging at $20^{\circ} \mathrm{C}$ for $86.4 \mathrm{ks}$ or $604.8 \mathrm{ks}$, then baked at $170^{\circ} \mathrm{C}$ for $1.2 \mathrm{ks}$.

短時間になることから，工業的に一定のベークハード性を安 定して得るためには, 高温予備時効の温度と時間の管理が重 要であることが明らかになった。そこで以降の実験において は, 高温予備時効処理の保持時間の影響が小さく，大きな ベークハード量が得られる $100^{\circ} \mathrm{C}$ の高温予備時効にてさらに 評価を行った。

$100^{\circ} \mathrm{C}$ の高温予備時効後に $20^{\circ} \mathrm{C}$ で $86.4 \mathrm{ks}$ あるいは $604.8 \mathrm{ks}$ の自然時効を行った場合の高温予備時効時間之 $\mathrm{BH}$ 処理前後 の硬さ, さらにBH 処理前後の硬さの差で表されるべーク ハード量を Fig. 4 に示す。自然時効時間が $86.4 \mathrm{ks}$ の場合, $\mathrm{BH}$ 処理前および $\mathrm{BH}$ 処理後の硬さは高温予備時効時間の増 加に伴い上昇した。 $3.6 \mathrm{ks}$ までの $100^{\circ} \mathrm{C}$ の高温予備時効にお いて，自然時効時間が $86.4 \mathrm{ks}$ と $604.8 \mathrm{ks}$ の場合を比較すると， $604.8 \mathrm{ks}$ の方が BH 処理前の硬さは高くなり, BH 処理後の硬 さは低くなった。高温予備時効が $3.6 \mathrm{ks}$ までのベークハード 量は, 自然時効 $86.4 \mathrm{ks}$ の場合は高温予備時効時間に伴い緩 やかに上昇, $604.8 \mathrm{ks}$ の場合は大きく上昇した。一方, 高温 予備時効時間が $7.2 \mathrm{ks}$ を越える長時間の場合は, 自然時効時 間が $86.4 \mathrm{ks}$ と $604.8 \mathrm{ks}$ ともほぼ同等の硬さになり，いずれも 高温予備時効時間の増加に伴いベークハード量が低下した。 したがって, $604.8 \mathrm{ks}$ の自然時効の場合には, 高温予備時効 が $100^{\circ} \mathrm{C}$ で $7.2 \mathrm{ks}$ の条件において最大のベークハード量となっ

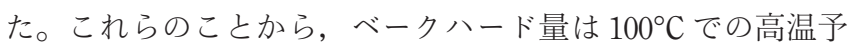
備時効時間とその後の自然時効時間の両方に影響されている ことが明らかになった。

さらにベークハード性に及ぼす高温予備時効時間とその後

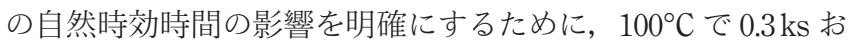
よび $7.2 \mathrm{ks}$ の高温予備時効を行った試料および比較として高 温予備時効なしの試料について, その後の自然時効時間の ベークハード性への影響を調査した。Fig. 5 に BH 処理前後 の耐力を示す。 $\mathrm{BH}$ 処理前において, 高温予備時効なし材の

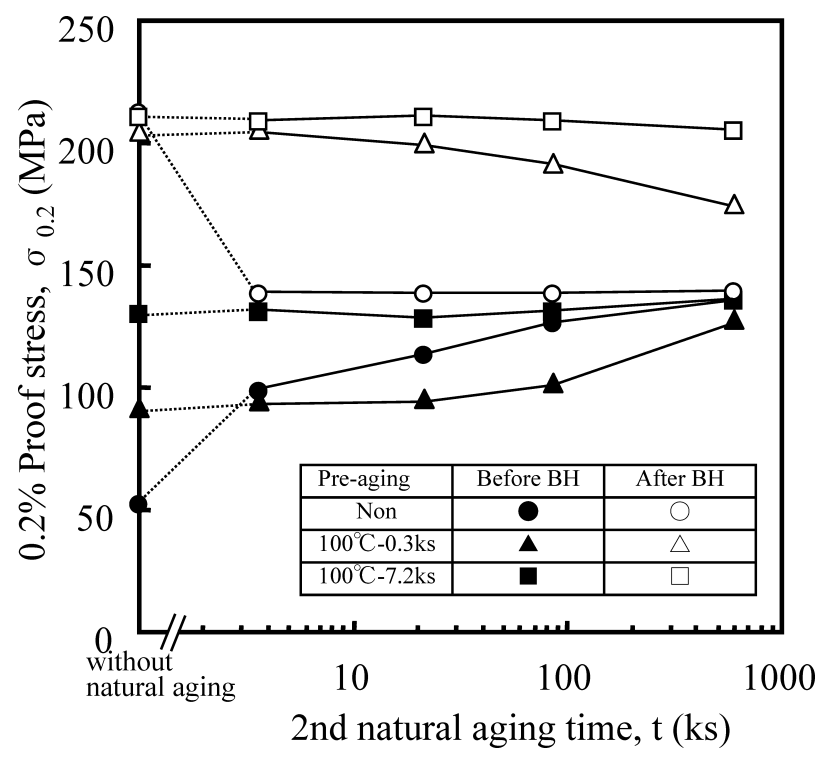

Fig. 5 Effect of 2 nd natural aging condition on the $0.2 \%$ proof stress of the alloy before $\mathrm{BH}$ treatment and after $\mathrm{BH}$ treatment. The samples were pre-aged at $100^{\circ} \mathrm{C}$ for $0.3 \mathrm{ks}$ or $7.2 \mathrm{ks}$ or not pre-aged after water quenching followed by 2nd natural aging at $20^{\circ} \mathrm{C}$ for various times, then baked at $170^{\circ} \mathrm{C}$ for $1.2 \mathrm{ks}$.

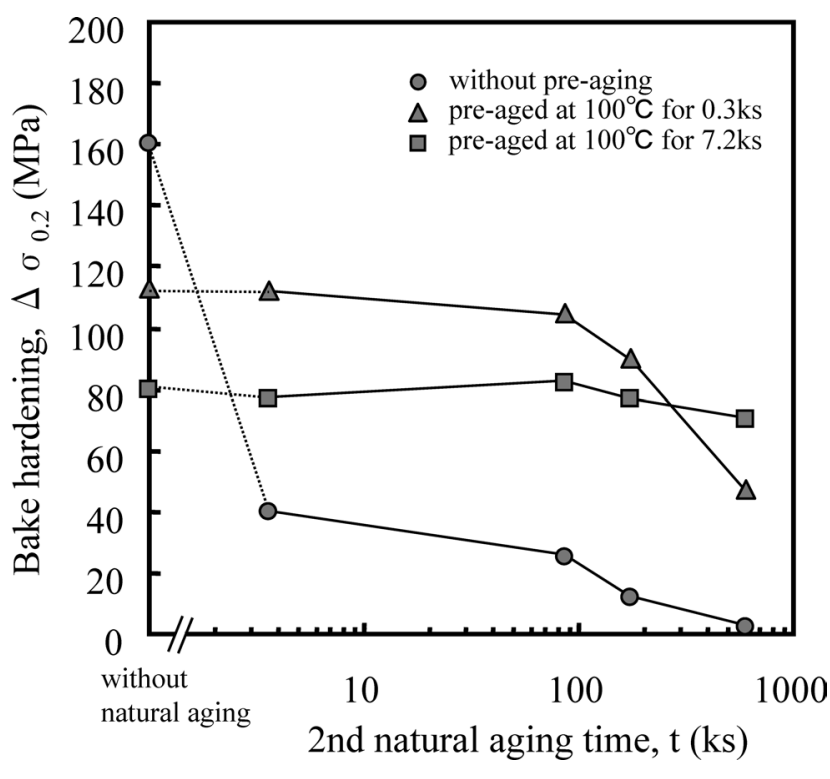

Fig. 6 Effect of 2nd natural aging condition on the bake hardnability for $0.2 \%$ proof stress. The samples were preaged at $100^{\circ} \mathrm{C}$ for $0.3 \mathrm{ks}$ or $7.2 \mathrm{ks}$ or not pre-aged after water quenching followed by 2 nd natural aging at $20^{\circ} \mathrm{C}$ for various times, them baked at $170^{\circ} \mathrm{C}$ for $1.2 \mathrm{ks}$.

耐力は自然時効開始直後から自然時効時間の経過に伴い急激

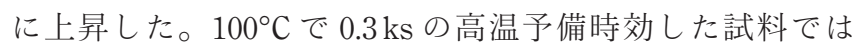
$86.4 \mathrm{ks}$ までほぼ耐力が一定でその後上昇したのに対し, $100^{\circ} \mathrm{C}$ で $7.2 \mathrm{ks}$ の高温予備時効を施した試料は自然時効が $604.8 \mathrm{ks}$ までほぼ一定の耐力であった。 BH 処理後の耐力は, 高温予 備時効なしの試料は自然時効時間の経過に伴い耐力が低下 し, $100^{\circ} \mathrm{C}$ で $0.3 \mathrm{ks}$ の高温予備時効した試料では $86.4 \mathrm{ks}$ まで, $100^{\circ} \mathrm{C}$ で $7.2 \mathrm{ks}$ の高温予備時効を施した試料では自然時効が $604.8 \mathrm{ks}$ まで高い耐力が得られた。Fig. 6 に自然時効時間と 


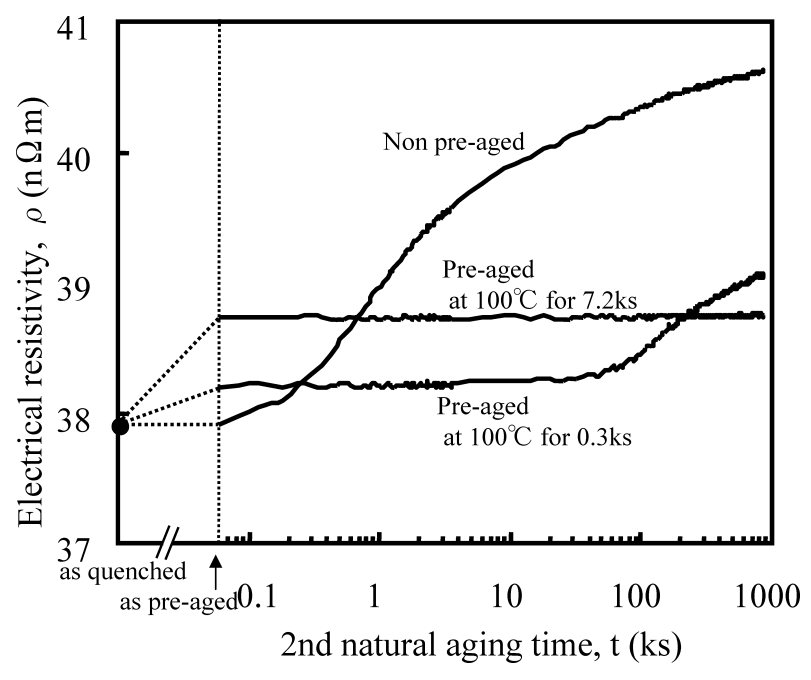

Fig. 7 In-situ measurement of the electrical resistivity during 2 nd natural aging at $20^{\circ} \mathrm{C}$ after water quenching or preaging at $100^{\circ} \mathrm{C}$ for $0.3 \mathrm{ks}$ and $7.2 \mathrm{ks}$.

ベークハード量の関係を示す。 $\mathrm{BH}$ 処理前後の耐力の差で表 されるベークハード量は, 高温予備時効なしでは自然時効時 間の増加に伴い低下したのに対し， $100^{\circ} \mathrm{C} て ゙ ~ 0.3 \mathrm{ks}$ の高温予

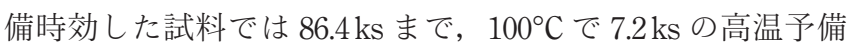
時効を施した試料は自然時効が $604.8 \mathrm{ks}$ まで大きなべーク ハード量が得られた。

このベークハード性の变化を解析するために, 電気抵抗測 定を行った。Fig. 7 に高温予備時効後の自然時効中の電気抵 抗についてその場測定した結果を示す。比較として高温予備 時効を施さなかった試料も併せて示す。 $20^{\circ} \mathrm{C}$ での自然時効に おいて, 高温予備時効なし材の場合には, 自然時効開始直後 より電気抵抗の大きな上昇がみられた。電気抵抗はアルミニ ウムマトリックスの固溶量の変化や母相に整合な組織の形成 などを総合して变化が生じる。本合金の焼入れ後の自然時効 においては，従来の報告 ${ }^{4)}$ を参考にしてクラス夕（1）の生 成の影響が大きいと仮定する。なお，ここでは山田らや芹澤 らの報告 7),11）を参考に, 自然時効中に生成され析出強化相の $\beta^{\prime \prime}$ 相に遷移しにくい原子の集合体をクラス夕 (1)， $\beta^{\prime \prime}$ 相の 前駆段階をクラス夕（2）と定義する。高温予備時効なし材 では自然時効時間の増加に伴い, 電気抵抗が急激に上昇する ことからクラスタ（1）の生成が促進していると推測される。 一方, $100^{\circ} \mathrm{C}$ で $0.3 \mathrm{ks}$ の高温予備時効を行った場合には, 自 然時効の初期には変化はみられず, $100 \mathrm{ks}$ 付近を越えると電 気抵抗の急激な上昇がみられた。これは $100 \mathrm{ks}$ 程度まではク ラス夕（1）の生成が抑制され，それ以上自然時効するとク ラス夕（1）が生成されることを示唆している。この結果は

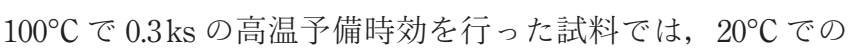
自然時効が $86.4 \mathrm{ks}$ を越えるとベークハード性が低下した結果 と一致した。 $100^{\circ} \mathrm{C}$ で $7.2 \mathrm{ks}$ の高温予備時効を施した試料で は, $20^{\circ} \mathrm{C}$ で $1000 \mathrm{ks}$ まで大きな電気抵抗の変化はみられなかっ たことから，自然時効中であクラス夕（1）の生成が少ない と推測された。

これらの結果より, 高温予備時効が十分でない場合には, ベークハード量の自然時効に伴う低下が電気抵抗の上昇と対 応することから, 自然時効は電気抵抗の上昇から推測される

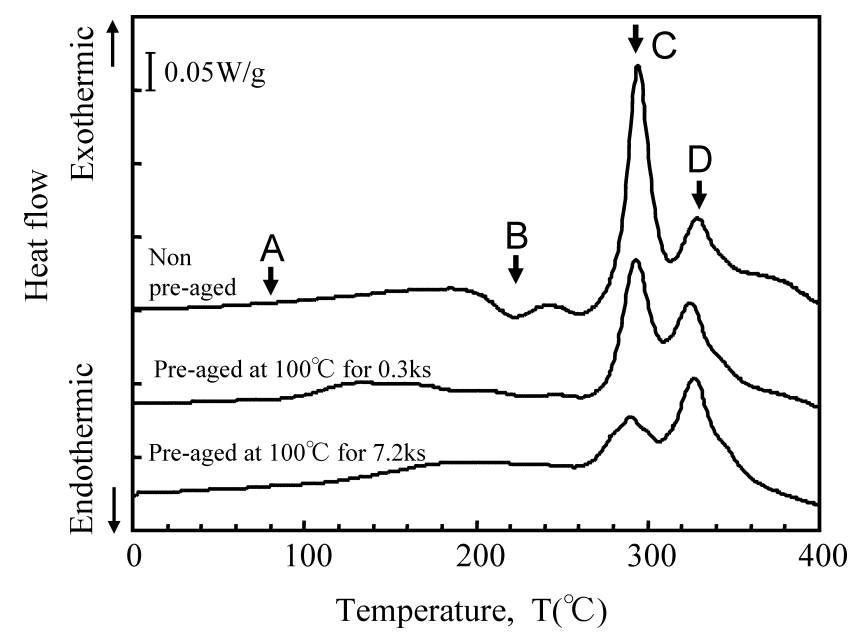

Fig. 8 DSC curves of 2nd natural aged samples before BH treatment. The samples were pre-aged at $100^{\circ} \mathrm{C}$ for $0.3 \mathrm{ks}$ or $7.2 \mathrm{ks}$ or not pre-aged after water quenching followed by 2nd natural aging at $20^{\circ} \mathrm{C}$ for $604.8 \mathrm{ks}$.

クラス夕（1）の生成を促進させていると考えられる。本来, 強化相である $\beta^{\prime \prime}$ 相を形成するためのアルミニウムマトリッ クス中に固溶しているマグネシウム, シリコンおよび凍結空 孔が，室温で安定なクラス夕（1）を生成するため, 見かけ 上それらの溶質原子执よび凍結空孔が減少し, ベークハード 性が低くなるむのと考えられる。

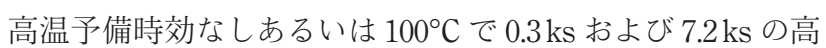
温予備時効を行った後, $604.8 \mathrm{ks}$ の自然時効を施した BH 処理 前試料の DSC 分析結果を Fig. 8 に示す。矢印 A の温度は, 焼入れ直後材に扣いてクラス夕（本報でクラス夕（1）と称 している）の生成が発熱ピークとして観察される温度である。 本調査の高温予備時効なし材は, 自然時効されてクラス夕 （1）がすでに生成しているため, 発熱ピークはほとんど観察 されなかった。吸熱ピーク B はクラス夕の溶解, 発熱ピーク $\mathrm{C}$ と D はそれぞれ $\beta^{\prime \prime}$ 相と $\beta^{\prime}$ 相の析出と言われている ${ }^{12)}$ 。高 温予備時効なし材ではクラス夕（1）の溶解による吸熱ピー クがみられ， $\beta^{\prime \prime}$ 相の析出に相当する発熱ピークが明瞭にみら れた。このことは高温予備時効なしの場合には自然時効中に クラス夕（1）が生成したことおよびクラス夕（1）が溶解し た後に $\beta^{\prime \prime}$ 相が析出することを示唆している。 $100^{\circ} \mathrm{C}$ で $0.3 \mathrm{ks}$ の高温予備時効を施した試料ではわずかにクラス夕（1）の

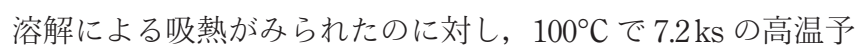
備時効を施した試料では吸熱ピークはみられなかった。この ことから, $100^{\circ} \mathrm{C}$ で $7.2 \mathrm{ks}$ の高温予備時効により, $20^{\circ} \mathrm{C}$ での 自然時効中のクラス夕（1）の生成が抑制されたものと推測 できる。

上述の電気抵抗測定において, 高温予備時効なしの試料で は自然時効の開始直後より電気抵抗の上昇がみられることか ら, 自然時効初期よりクラス夕（1）の生成が始まっている ことを推測した。そこで, 焼入れ後 $100^{\circ} \mathrm{C}$ の高温予備時効を 開始する前に自然時効を施した四段時効を行い, 高温予備時 効前の自然時効の影響を調查した。高温予備時効開始前の $20^{\circ} \mathrm{C}$ での自然時効時間と $\mathrm{BH}$ 処理前後の耐力およびベーク ハード量を Fig. 9 に示す。焼入れ直後に $100^{\circ} \mathrm{C}$ で高温予備時 効した場合には, BH 処理前の耐力が低く $\mathrm{BH}$ 処理後の耐力 


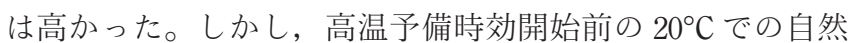
時効時間の増加に伴い $\mathrm{BH}$ 処理前の耐力は上昇し, $\mathrm{BH}$ 処理 後の耐力は小さくなった。 $\mathrm{BH}$ 前後の耐力の差で表されるべー クハード量は高温予備時効開始前の $20^{\circ} \mathrm{C}$ での自然時効時間 の増加に伴い，短時間で減少した。この結果は，従来報告さ れている二段時効におけるべークハード性に及ぼす自然時効 の影響 4),9) と一致した。

焼入れ直後に $100^{\circ} \mathrm{C}$ で $7.2 \mathrm{ks}$ の高温予備時効を行った試料 と，焼入れ後に $20^{\circ} \mathrm{C}$ で $1.8 \mathrm{ks}$ の自然時効を行った後に同様の

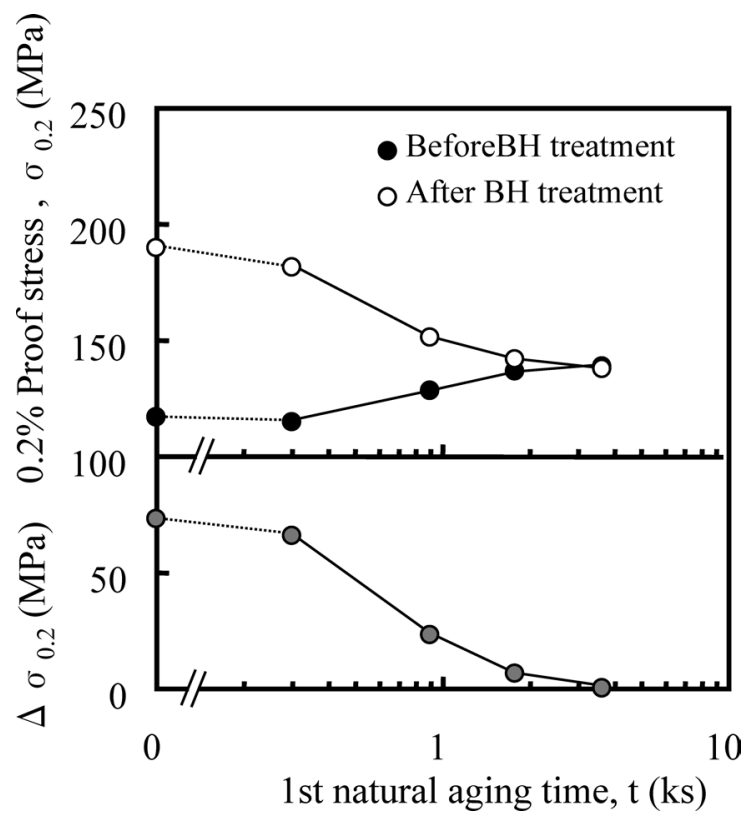

Fig. 9 Effect of 1 st natural aging condition on the $0.2 \%$ proof stress of the alloy before $\mathrm{BH}$ treatment and after $\mathrm{BH}$ treatment. The samples were pre-aged at $100^{\circ} \mathrm{C}$ for $3.6 \mathrm{ks}$ after water quenching and 1st natural aging followed by 2nd natural aging at $20^{\circ} \mathrm{C}$ for $86.4 \mathrm{ks}$, then baked at $170^{\circ} \mathrm{C}$ for $1.2 \mathrm{ks}$.
高温予備時効を行った試料について, 高温予備時効後の自然 時効中の電気抵抗を Fig. 10 に示す。いずれの試料でも, 自 然時効中に大きな電気抵抗変化はみられなかったが，焼入れ 後に $20^{\circ} \mathrm{C}$ で $1.8 \mathrm{ks}$ の自然時効を行った後に高温予備時効を 行った場合は, 初期から高い電気抵抗を示した。これは高温 予備時効前の $20^{\circ} \mathrm{C}$ で $1.8 \mathrm{ks}$ の自然時効中に, 安定なクラス夕 （1）が生成したため電気抵抗が高くなり, その後の高温予備 時効であ溶解されず残存したためと考えられる。そのため, 焼入れ後に $20^{\circ} \mathrm{C}$ で $1.8 \mathrm{ks}$ の自然時効を行った後に $100^{\circ} \mathrm{C}$ で $7.2 \mathrm{ks}$ の高温予備時効を行った試料は, ベークハード性が低 かったと考えられた。

クラスタ（1）および（2）の生成に及ぼす高温予備時効時 間之高温予備時効前後の自然時効の影響を模式図として Fig. 11 に示す。焼入れ後, 直ちに十分な時間の高温予備時効が 施されると, クラス夕（2）が多く生成され，クラス夕を生

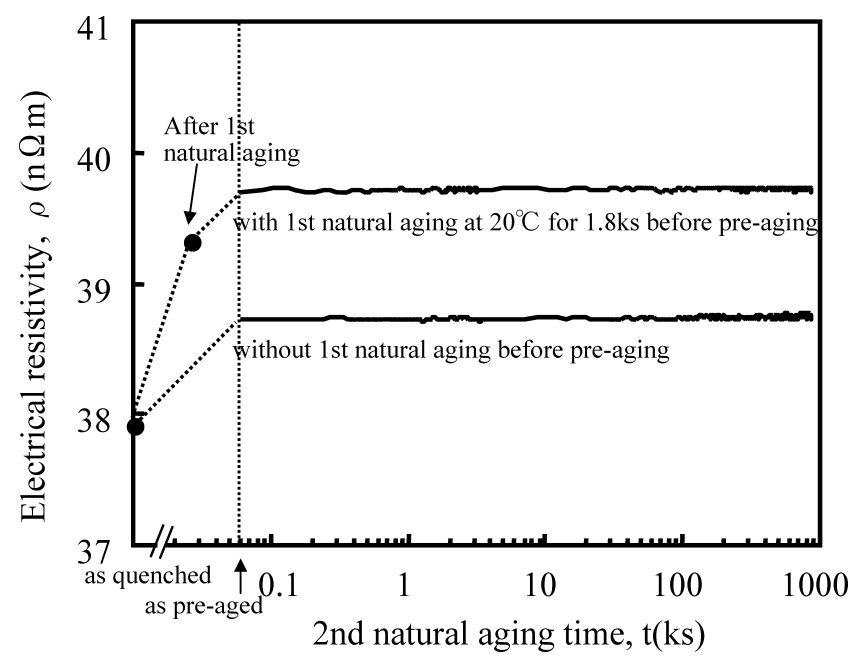

Fig. 10 In-situ measurement of the electrical resistivity during 2 nd natural aging at $20^{\circ} \mathrm{C}$ after pre-aging at $100^{\circ} \mathrm{C}$ for $7.2 \mathrm{ks}$.

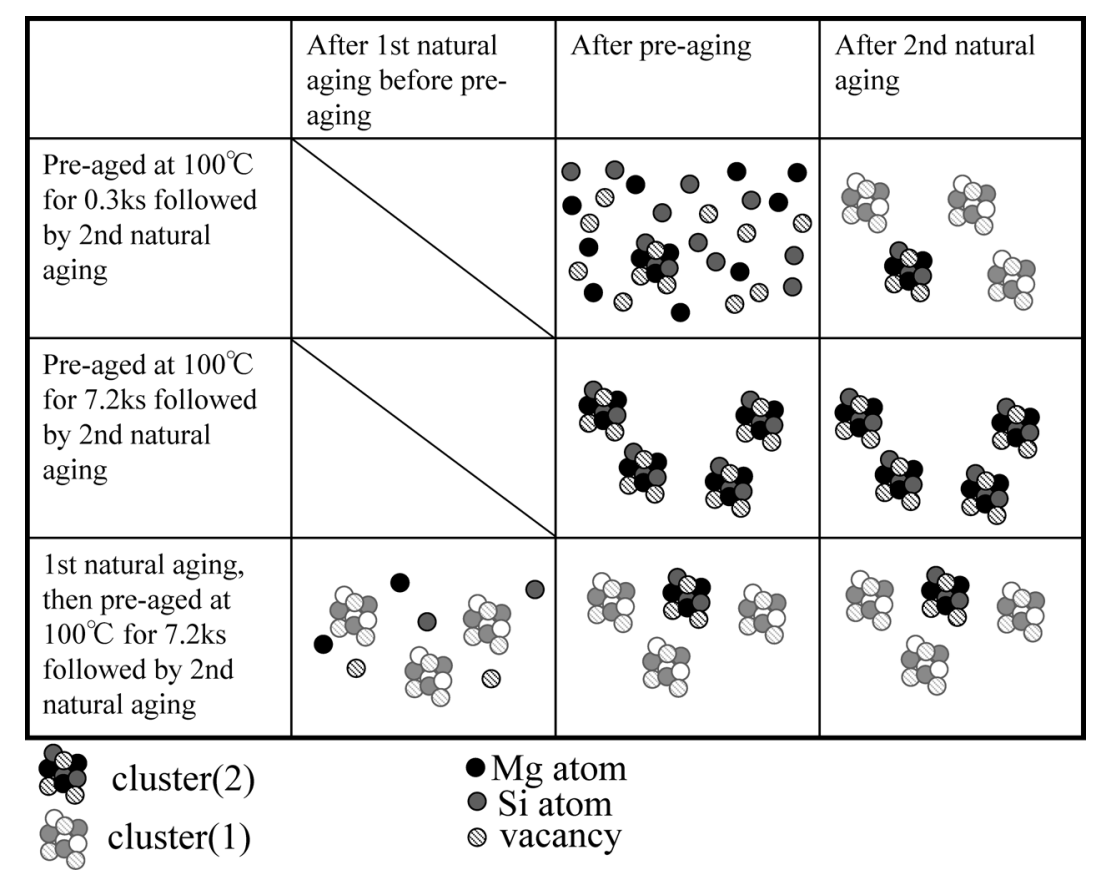

Fig. 11 The proposed mechanism for the formation of cluster (1) and cluster (2) ${ }^{7), 11}$ during various aging treatments. 
成していない溶質原子および凍結空孔濃度が減少する。その ため，後に続く自然時効においてクラス夕（1）の生成を抑 制できると考えられる。一方, 高温予備時効時間が短い場合 にはクラス夕（2）の生成が少なく，クラス夕を生成してい ない溶質原子および凍結空孔が母相中に多く残存するために, 潜伏期間の後にクラス夕（1）の生成が開始する。その結果, 長時間の自然時効の後にベークハード性が低下する。また, 高温予備時効前に自然時効が存在する場合には, 自然時効に おいてクラス夕（1）が優先して生成し，高温予備時効およ びその後の自然時効, さらにBH 処理中でもクラス夕 (1) が 安定して存在する。そのために高いベークハード性が得られ ないと考えられる。これらことから，焼入れ後にクラス夕 （1）が生成する前に適切な条件で十分な高温予備時効処理を 行うことが高いベークハード性を得るためには重要であると 考えられる。

\section{4. 結言}

$\mathrm{Al}-0.62 \% \mathrm{Mg}-0.96 \% \mathrm{Si}$ 合金について, ベークハード性に及 ぼす高温予備時効とその前後の自然時効の影響について調査 した。得られた結果を以下にまとめる。

（1）焼入れ直後に $100^{\circ} \mathrm{C}$ から $170^{\circ} \mathrm{C}$ の高温予備時効処理を 行うことにより, $86.4 \mathrm{ks}$ の自然時効後でも高いベークハード 性が得られる。

(2) $100^{\circ} \mathrm{C}$ の高温予備時効処理において, 高温予備時効時 間が短い場合には高ベークハード性を得るための自然時効時 間が限定される。これは自然時効が一定時間を越えると $\beta^{\prime \prime}$ 相に遷移しないクラス夕の生成が生じるためと考えられる。

（3）焼入れ後から高温予備時効処理を開始するまでに自然
時効が存在すると, 高温予備時効を施しても高いベークハー ド性が得られない。これは高温予備時効前の自然時効におい て優先して $\beta^{\prime \prime}$ 相に遷移しないクラス夕が生成され, 高温予 備時効しても残存しているためと推測される。

本研究は新エネルギー・産業技術総合開発機構 (NEDO) から財)金属系材料研究開発センター (JRCM) への委託研究 「実用金属材料分野ナノメタル技術開発（アルミニウム系サ ブグループ)」の一環として行ったあのである。

\section{参 考 文 献}

1）宇都秀之：住友軽金属技報，47（2006），128-144.

2) J. Langerweger: Proc.Aluminium Technology '86, (ed. T. Sheppard), The Institute of Metals, (1986), 216-222.

3）馬場義雄, 高島 章：軽金属, 19 (1969), 90-98.

4）八太秀周, 田中宏樹, 松田眞一, 吉田英雄：軽金属, 54 (2004), 412-417.

5）八太秀周, 松田眞一, 吉田英雄 : 軽金属, 56 (2006), 667672.

6）櫻井健夫, 高木康夫, 増田哲也：軽金属学会第 98 回春期大会 講演概要, (2000), 187-188.

7）山田健太郎, 里 達雄, 神尾彰彦 : 軽金属, 51 (2001), 215-221.

8）里 達雄, 山田健太郎, 神尾彰彦 : 軽金属, 49 (1999), 450-451.

9）佐賀 誠, 佐々木行雄, 菊地正夫, 日比野旭, 松尾 守：軽金 属, $\mathbf{5 3}$ (2003)， 516-522.

10）内田秀俊, 吉田英雄：軽金属, 46 (1996), 427-431.

11) A. Serizawa, S. Hirosawa and T. Sato: Materials Science Forum, 519-521 (2006), 245-250.

12) A. K. Gupta and D. J. Lloyd: Proceedings of the 3rd International Conference on Aluminum Alloys, 2 (1994), 21-25. 